\title{
A Pharmacognosy Approach to the Botanical Source of a Cinnamon Fruit Traded as Nägakeśara and Sirunagappu in Raw Drug Markets
}

\author{
Chinnapillai Arunachalam ${ }^{1}$, Balasundaram Maheshwari ${ }^{1}$, Govindarajan Nartunai ${ }^{1}$, Raju Ilavarasan ${ }^{1}$, Koppala \\ Narayana Sunil Kumar ${ }^{1,2^{*}}$, Parameswaran Sathiyarajeswaran²
}

\section{Chinnapillai Arunacha- lam $^{1}$, Balasundaram Maheshwari', Govinda- rajan Nartunai ${ }^{1}$, Raju Ilavarasan ${ }^{1}$, Koppala Narayana Sunil Kumar ${ }^{1,2^{*} \text {, }}$ Parameswaran Sathiya- rajeswaran $^{2}$}

\section{'Department of Pharmacognosy, Captain Srinivasa Murthy Regional Ayurveda Drug Development Institute India, Chennai- 600106, Tamil Nadu, INDIA. \\ 2Siddha Central Research Institute, Arignar Anna Hospital Campus, Arumbakkam, Chennai- 600106, Tamil Nadu, INDIA. \\ Correspondence \\ Dr. KN Sunil Kumar \\ Siddha Central Research Institute, Chennai- 600106, Tamil Nadu, INDIA. Phone no : +91-7406111071 \\ E-mail:kn.sunil@gov.in \\ History \\ - Submission Date: 05-06-2018; \\ - Review completed: 02-08-2018; \\ - Accepted Date: 07-09-2018}

DOI : 10.5530/pj.2019.1.15

Article Available online http://www.phcogj.com/v11/i1

\section{Copyright}

(C) 2019 Phcog.Net. This is an openaccess article distributed under the terms of the Creative Commons Attribution 4.0 International license.

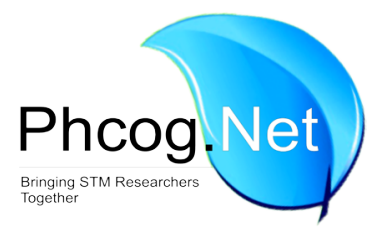

\begin{abstract}
Background: Adulteration and substitution of Nagakesara is a well-established fact in the medicinal plant literature though it is referred by the authors of important Ayurvedic texts to cure piles, dysentery, hiccup etc. The botanical identities of controversial sources of Nagakesara are flowers of Mesua ferrea L. and Ochrocarpus longifolius Benth. and Hook. f., Calophyllum inophyllum L., Dillenia pentagyna Roxb. and perchance their allied species. Though immature fruits of some Cinnamomum species are also reported to be sold as Nagakesara/Sirunagappu in the crude drug markets there are no pharmacognostic studies available for the identification and analysis of this crude drug. Materials and Methods: In this study, marketed Nagakesara/ Sirunagappu samples were procured from Chennai raw drug market and analyzed as per the standard methodologies for pharmacognostic studies. Results: Macro-microscopical characters and chemical identity of the samples of immature fruits were established to derive set of characters for the identification of this marketed material. The proposed results would help in identification of this crude drug while used as substitute drug for the official source. Conclusion: The botanical Nagakesara or Sirunagappu is neither stamen nor flower, but it is fruit of Cinnamomum species. As Western Ghats is habitat for several similar looking species of Cinnamomum, there is necessity to study the pharmacognostical characters of all species of Cinnamomum before concluding the botanical source of this ambiguous raw drug of Ayurveda and Siddha.
\end{abstract}

Key words: Adulteration, HPTLC, Lauraceae, Market substitute, Quality standards, Siddha.

\section{INTRODUCTION}

Even though various documents prescribe standards for drugs of vegetable origin, problem of identity is a threat to the quality of several medicines of traditional systems of medicine. It is a great challenge for a large scale manufacturer of Ayurveda or Siddha formulations as they wholly depend on drugs from market. Due to the overwhelming demand for some less produced raw drugs, crude drug traders always look for an alternate to keep the supply as per demand. Recently, there is increasing trend in entry of new commodities as substitutes for certain raw drugs, the reason may be attributed to high demand and disturbed frequency of the occurrence of the source plant. Identity of marketed drugs is need of the hour when quality of the herbal medicines is seriously considered. Nagakeshara is referred by the authors of important Ayurvedic texts to cure piles, dysentery, hiccup etc. The botanical identities of controversial sources of Nāgakeśara are flowers of Mesua ferrea L. and Ochrocarpus longifolius Benth. and Hook. f., Calophyllum inophyllum L. and Dillenia pentagyna Roxb. ${ }^{1}$

In the past, immature fruits of Cinnamomum species were also reported to be traded in place of Nagakeshara both as a substitute and as an adulterant. Among fruits of Cinnamomum species under trade in India, C. malabatrum Reinw. is used in pan as a substitute for clove buds. ${ }^{2}$ C. malabatrum is a close relative of C. verum and is a highly variable species occurring in south India and are found in the Western Ghats and adjoining areas. Kattu karuva described by Van Rheede in Hortus Malabaricus (1685) 3 was nothing but C. malabatrum. Species described under C. iners by Hooker $(1886)^{4}$ as well as Gamble $(1925)^{5}$ also refer to C. malabatrum. This is a moderately sized tree, sometimes attaining larger proportions. Fruit ellipsoid, up to 8 to $10 \mathrm{~mm}$, cup deep, rather fleshy, the base merging to the pedicel, the rim, with persistent thickened tepals of which the apical part drops off, the basal part rounded and pilose. ${ }^{6}$

Sirunagappu is one of the important drugs used in Siddha system of medicine. There is a lot of confusion existing in the botanical source

Cite this article: Arunachalam C, Maheshwari B, Nartunai G, Ilavarasan R, Sunil Kumar KN, Sathiyarajeswaran P. A Pharmacognosy Approach to the Botanical Source of a Cinnamon Fruit Traded as Nagakesara and Sirunagappu in Raw Drug Markets. Pharmacog J. 2019;11(1):81-7. 
of this drug. Cinnamomum wightii Meissn. is endemic to Shola forests of Southern Western Ghats in Tamil Nadu (Annamalai, Palani, Nilgiris, Coimbatore, Dindigul) and Kerala (Idukki, Palakkad, Wayanad, Thiruvanthapuram) is a tree, up to $8 \mathrm{~m}$ tall with angular young branchlets, fruit is ellipsoid one seeded berry, up to $1.5 \mathrm{~cm}$ long; fruiting perianth cup fleshy, obconical with basal remnants lobes. It is claimed that flower buds of C. wightii are used as Sirunagappu in preparation of Siddha formulation such as Amukkura curnam. ${ }^{7}$ Tender fruits including style and calyx are astringent, aromatic, stimulant and carminative, it is also used to treat wounds, fever, intestinal worms, headache and menstrual problems. ${ }^{8}$

The current investigation is planned to explore pharmacognostical identity of a fruit sample which is found commonly in Chennai raw drug markets in the name of Nagakesara and Sirunagappu.

\section{MATERIALS AND METHODS}

\section{Materials}

Dried flower buds sold as Nagakeshara/Sirunagappu were procured from Chennai market and the macroscopic characters observed referring to The Flora of Presidency of Madras ${ }^{5}$ and a dried specimen (No: 00643) was deposited in museum of CSMRADDI Chennai. The flower bud was used for the study of macroscopic and microscopic characters. Dried powder was examined for physico-chemical analysis, extraction, phytochemical study and HPTLC fingerprinting.

\section{Methods}

\section{Macro-microscopical study}

The fruits were examined for macroscopy as per standard procedures. For microscopic study specimens were cut into thin transverse section using a sharp blade and the sections were stained with safranin. Transverse sections were photographed using Zeiss AXIO trinocular microscope attached with Zeiss AxioCam camera under bright field light. Magnifications of the figures are indicated by the scale-bars. ${ }^{9}$

\section{Physico-chemical and preliminary phytochemical analysis}

Physico-chemical studies like loss on drying at $105^{\circ} \mathrm{C}$, total ash, acid insoluble ash, water-soluble ash, alkalinity of water soluble ash, water soluble extractive and alcohol soluble extractive were carried out as per WHO guidelines. ${ }^{10} \mathrm{~A}$ known quantity of dried powder was extracted in Soxhlet with petroleum ether $\left(60-80^{\circ} \mathrm{C}\right)$, chloroform, ethyl acetate, alcohol and finally with water successively and tested for different constituents and preliminary phytochemical tests were done as per the standard methods. ${ }^{11,12}$ The fluorescence behavior of the powdered drug in the day light and ultraviolet light were done by moistening the powder in different solution and viewing under the light of different wavelengths in a UV-chamber.

\section{High performance thin layer chromatography}

About $4 \mathrm{~g}$ of the coarse plant material were successively extracted in Soxhlet apparatus using $n$-hexane, chloroform ethyl acetate and alcohol. The corresponding extracts were filtered, concentrated and made up to $10 \mathrm{ml}$ in a standard flask. 5, 10 and $15 \mu$ of this solution were applied on (E. Merck) aluminum plate percolated with silica gel $60 \mathrm{~F}_{254}$ of 0.2 $\mathrm{mm}$ thickness, CAMAG Linomat IV applicator was used for applying the spot on plates. The plates were developed in a twin trough chamber, saturated with the established solvent system before $30 \mathrm{~min}$, to a distance of $8 \mathrm{~cm}$. The plate was visualized under in UV 254 and $366 \mathrm{~nm}$. The air dried plate was dipped in vanillin-sulphuric acid reagent and then kept in oven at $105^{\circ} \mathrm{C}$ till the colour of the spots appeared. The photographs were taken. ${ }^{13-15}$

\section{RESULTS AND DISCUSSION}

\section{Macroscopy}

The sample consists of mixture of 1 to $2 \mathrm{~cm}$ long fragments of slender peduncles, globose to round infected buds forming gall-like structures and 0.3 to $0.5 \mathrm{~cm}$ long, oval to elliptical fruits which are often detached from the perianth forming cup-like structure on the thalamus; galls can be easily differentiated by the absence of perianth cups formed from accrescent tepals of the flowers; dark chocolate brown externally and light brown internally, encloses elliptical, off-white fruit in it (Figure 1); the galls are astringent in taste and slight in odour while the fruits are astringent-aromatic in taste and fragrant in odour.

\section{Microscopy}

Stalk: TS of stalk is roughly triangular in outline, shows an outer single layer of epidermis having 2 to 4 celled cortex with volatile oil cavities and mucilage cells; discontinuous pericycle formed by group of stone cells; 3 major vascular bundles composed of xylem and phloem; and central pith occupied by stone cells (Figure 2a). When a portion of TS is enlarged, there is an epidermis with outer thick wall, coated with cuticle, bearing unicellular short conical covering trichomes; the cortex is formed by tightly packed parenchyma embedding lot of volatile oil cavities and few mucilage cells; pericycle is formed groups of wide-lumen sclereids; phloem shows cells with yellow contents; xylem shows rows of vessels; the central pith region shows lot of sclereids of varying thickness (Figure 2b).

Perianth cup: TS through perianth cup shows an outer epidermis bearing trichomes similar to that of stalk; beneath outer epidermis there are layers of closely packed parenchyma having a few mucilage cells; the ground tissue is formed by few parenchyma and many small groups of wide-lumen sclereids; the inner epidermis does not clearly show the cells but formed my crushed parenchyma cells having groups of thick-walled sclereids in groups; outer to inner epidermis there are masses of remnant tissue may be part of withered inner perianth (Figure 2c).

Fruit wall: TS through wall of the fruit shows an epicarp with outer thick walled cuticle; below the epicarp there is a hypocarp formed by comparatively large sized parenchyma cells with contents; the outer mesocarp shows groups of thick-walled narrow lumen sclereids while the inner mesocarp has large parenchyma without stone cells; a few idioblasts containing some granular contents are embedded in the inner mesocarp regions; the endocarp is formed by small sized parenchyma cells which are very closely packed; tissue of immature seed such as testa and endosperm are also attached to the endocarp, the centre of the immature seed being hollow (Figure 2d).

Macerate: When portion of stalk with attached perianth cup is macerated it shows thick-walled polygonal cells of epidermis of calyx in surface view having few cicatrix; thick-walled unicellular covering bent trichomes with basal cells; idioblasts containing fully swollen mucilage cells attached to normal parenchyma; spherical to elongated volatile oil containing cells; thick-walled parenchyma with sandy crystals; isolated to groups of broad-lumen sclereids of various sizes and shapes; wide lumen tracheidal fibre with pointed ends; elongated sclereidal fibres; scalariform tracheid with pointed ends; and annular vessels (Figure 3a-o). When fruit wall is macerated it shows polygonal epicarp cells with beaded walls; short reticulate tracheids in groups; large idioblasts containing fully swollen mucilage; isolated to groups of narrow-lumen sclereids of various sizes and shapes; elongated sclereidal fibres; tiny narrow lumen stone cells; spirally thickened tracheids and vessels; and fragment of thick-walled cells from epicarp of basal region of fruit (Figure 4a-o).

Powder: Powder shows a few unicellular conical trichomes, parenchyma with idioblasts containing mucilage and volatile oil cells; lot of stone cells/ sclereids of various sizes and shapes; elongated thick-walled sclereidal 


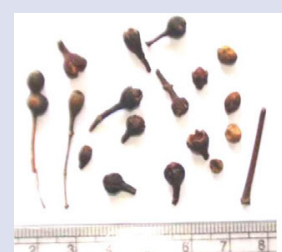

A

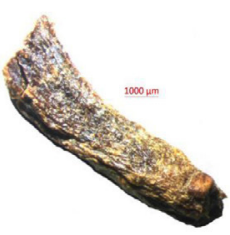

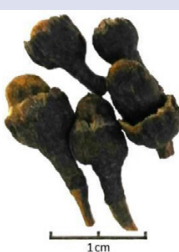

B

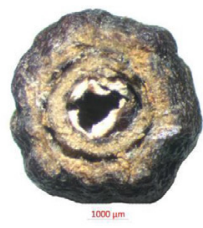

E

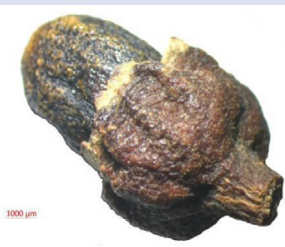

C

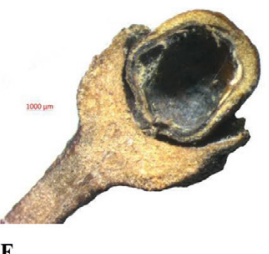

Figure 1: Macroscopy of Nagakeshara/Sirunagappu. A. Fruits with stalks and galls, B. Fruits enlarged, C. A single fruit enlarged, D. Stalk enlarged, E. Transversely cut fruit, F. Longitudinally cut fruit.

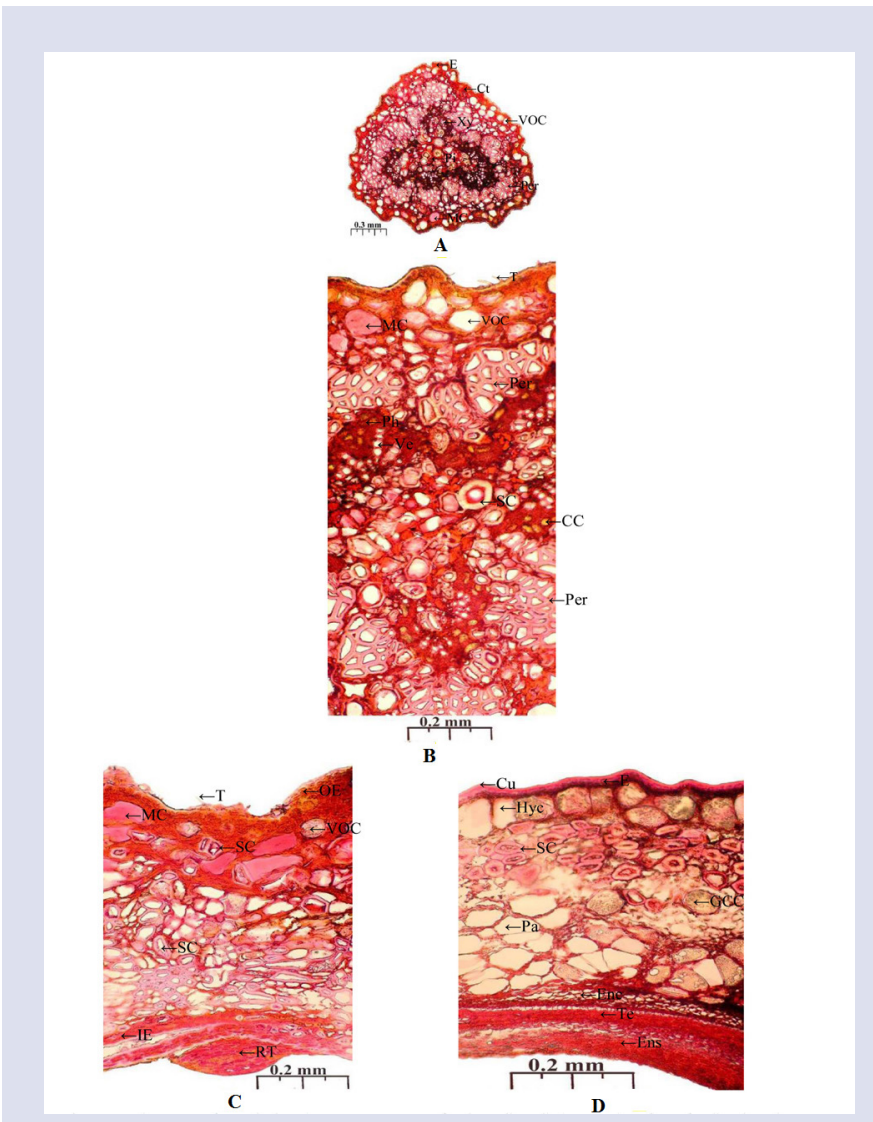

Figure 2: Microscopy of Nagakeshara/Sirunagappu. A. TS of entire stalk, stalk, b. A portion of TS of stalk enlarged, c. TS through perianth cup, d. TS of fruit. CC - content cell, Ct - cortex, Cu - cuticle, E - epidermis, Enc - endocarp, Ens - endosperm, GCC - granular content cell, Hyc - hypocarp, IE - inner epidermis, MC - mucilage cells, OE - outer epidermis, $\mathrm{Pa}$ - parenchyma, Per - pericycle, $\mathrm{Ph}$ - phloem, $\mathrm{Pi}$ - pith, RT - remnant tissue, SC - stone cell/sclereid, T - trichome, Te - testa, Ve - vessel, VOC volatile oil cell, $\mathrm{Xy}$ - xylem.

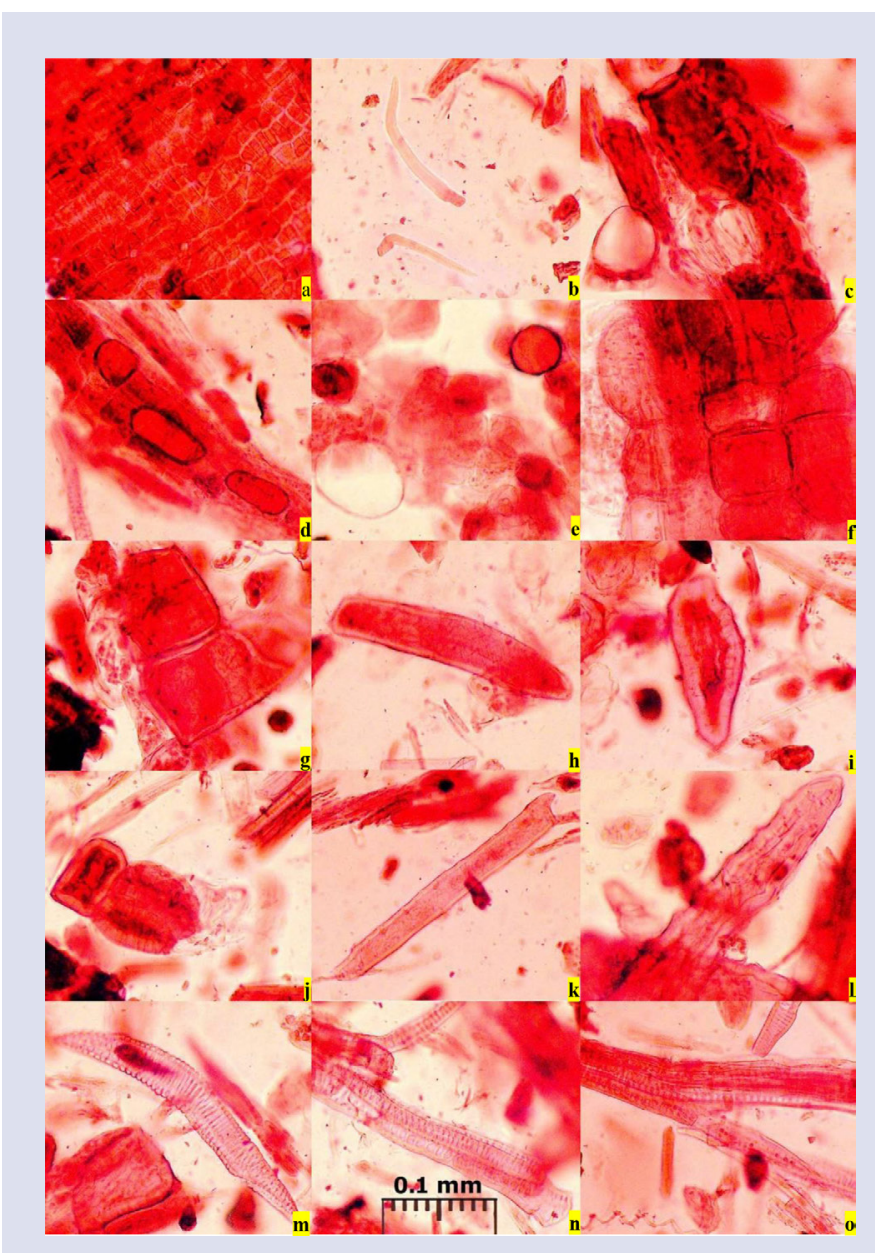

Figure 3: Microscopic characters of isolated elements of perianth cup of Nagakeshara/Sirunagappu. a. Epidermis of calyx in surface view; b. Unicellular covering trichomes; c. Parenchyma with mucilage; d,e. Volatile oil cells; f. Pitted parenchyma; $g-j$. Stone cells/sclereids; k. Fibre; I. Fibrosclereid; m. Scalariform tracheid; n,o. Annular vessels.

fibres; and fragments of vascular bundles with scalariform tracheids (Figure 5); powder is reddish brown in colour with pleasant odour and mucilaginous slightly astringent taste.

\section{Fluorescence behavior}

Fluorescence testing is one of the tests used for identification of several herbal drug powders ever since the origin of phytochemistry. When a drug powder is treated with some acidic or alkaline reagent, the phytochemical present in the sample undergo chemical changes which in turn produces some fluorescence behavior when exposed to lights of different wavelength. Examination of the powder of the sample under investigation showed yellow fluorescence with ethanol and methanol, purple fluorescence with acetone and green fluorescence with methanolic/ethanolic $\mathrm{NaOH}$ when observed under long UV; other characteristic colour were observed under white light and short UV with different reagents (Table 1). These colour characteristics can be used to detect the raw drug without much expenses in short period of time.

\section{Physico-chemical standards}

The physico-chemical parameters such as loss on drying, water soluble extractive, ethanol soluble extractive, total ash, water-soluble ash and 


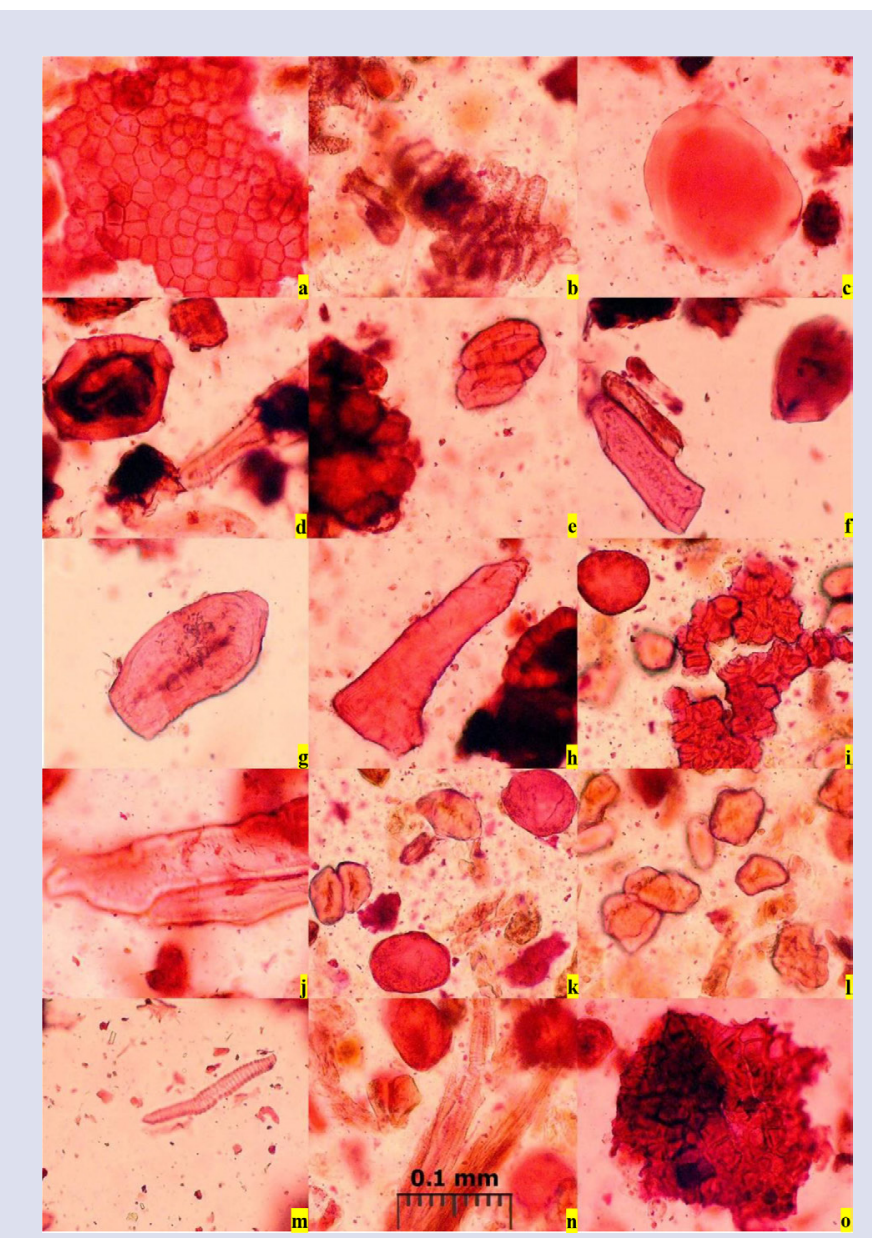

Figure 4: Microscopic characters of isolated elements of fruit wall of Nagakeshara/Sirunagappu. a. Epicarp cells in surface view; b. Reticulate parenchyma; c. Mucilage cell; d-h. Sclereids; i. Cells from epicarp of basal region of fruit; j. Sclereidal fibres; k,l. Stone cells; m. Tracheid; $n$. Spiral vessels; $\mathrm{o}$. Cells from epicarp of basal region of fruit.

acid insoluble ash are important observations towards authenticity and quality affirmation of botanical drugs. Loss on drying the drug was $8.51 \%$ revealing the moisture percentage in the drug. Total ash is found to be $(3.82 \%)$ while acid insoluble and water soluble ash is found to be 1.03 and $0.38 \%$ respectively. The water soluble extractive value was $5.76 \% \mathrm{w} / \mathrm{w}$ indicating the presence of readily water soluble polar constituents such as sugars, amino acids and inorganic salts. The ethanol soluble extractive value was $3.41 \%$ indicating the percentage of medium polar constituents of the plant material (Table 2).

\section{Preliminary phytochemical tests}

The preliminary phytochemical investigation of different extracts of the drug showed the presence of different moieties of phytochemicals. Triterpenoid was present in $n$-hexane, chloroform, ethyl acetate and ethanol extracts; flavanoids were detected in ethyl acetate and ethanol extracts; carbohydrates were present in ethanol extract; quinines, tannin and phenolic compounds were present in ethyl acetate and ethanol extracts; furan was detected from chloroform, ethyl acetate and ethanol extracts (Table 3). The medicinal activity of an herbal drug is due to the presence of these metabolites and these phytochemical moieties are helpful in proposing probable action of the plant drug.

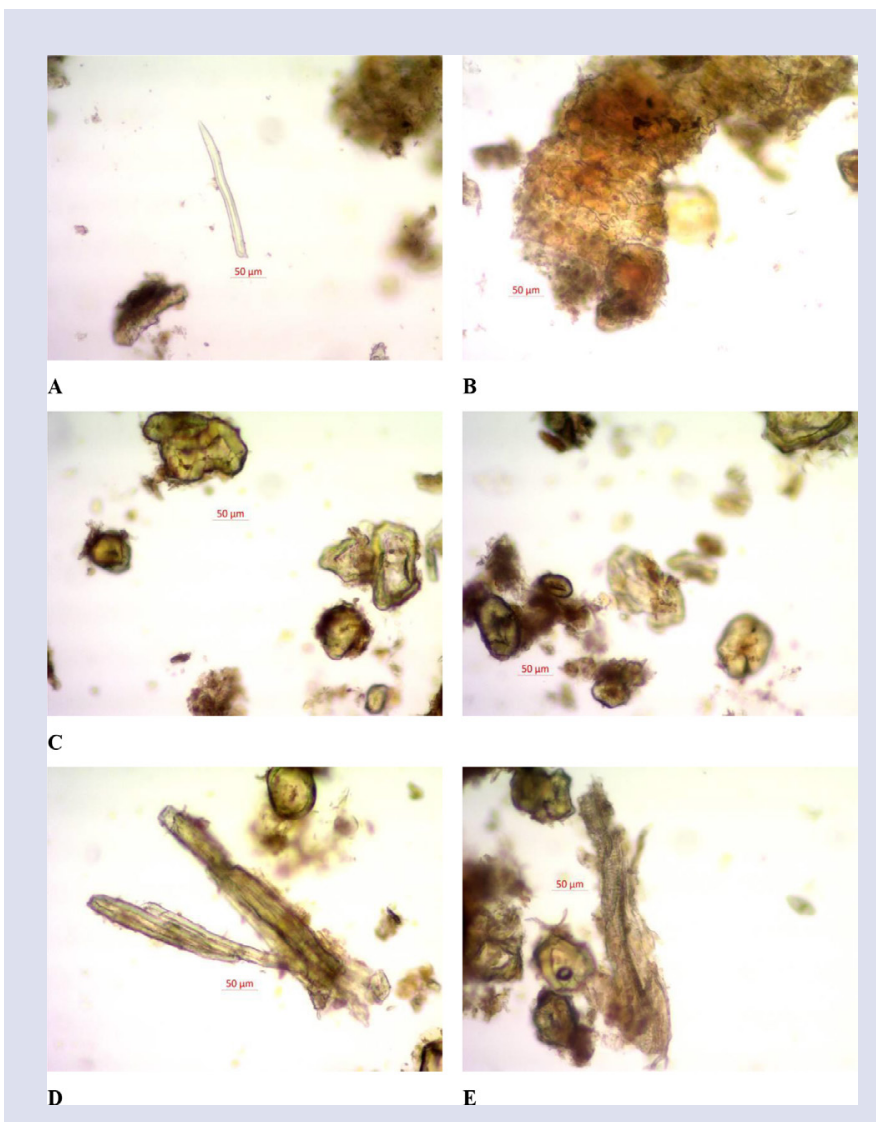

Figure 5: Microscopic characters of powder of fruit with stalk and perianth cup of Nagakeshara/Sirunagappu. a. Trichome; b. Parenchyma with mucilage and volatile oil cells; c. Stone cells/sclereids of different sizes and shapes; $d$. Sclereidal fibres; e. Scalariform tracheids.

\section{High Performance Thin Layer Chromatography (HPTLC)}

HPTLC fingerprinting revealed the presence of various phytoconstituents with their respective $R_{f}$ values and the photo documentation of the plates showed numerous bands under short UV, long UV and after derivatisation. Vanillin-sulphuric acid reagent was used as visualizing agent to effect visualization of the resolved spots. $n$-Hexane, chloroform, ethyl acetate and ethanol extracts were fingerprinted using solvent system toluene and ethyl as mobile phase. Extracts showed different banding pattern useful for identification of different extracts under different visualization techniques. n-Hexane extract showed 8, 6 and 8 spots under short UV, long UV and after derivatization respectively (Figure 6a); chloroform extract showed 6, 11 and 10 spots under short UV, long UV and after derivatization respectively (Figure 6b); ethyl acetate extract showed 9, 7 and 6 spots under short UV, long UV and after derivatization respectively (Figure 6c); and ethanol extract showed 3, 7 and 4 spots under short UV, long UV and after derivatization respectively (Figure 6d). As ethyl acetate extract showed good fingerprint pattern on photodocumentation it was chosen for HPTLC studies. Densitometric scan at $620 \mathrm{~nm}$ (post derivatization) showed 18 peaks with $\mathrm{R}_{\mathrm{f}} 0.05(8.44 \%)$, 0.08 (0.93\%), 0.16 (3.05\%), 0.20 (0.74\%), 0.25 (7.17\%), 0.27 (3.63\%), $0.31(4.56 \%), 0.39(0.72 \%), 0.44(1.18 \%), 0.46(0.67 \%), 0.50(1.01 \%)$, 0.57 (1.02\%), 0.62 (3.36\%), 0.66 (0.85\%), 0.73 (4.25\%), 0.77 (6.78\%), $0.81(2.85 \%)$ and $0.86(8.79 \%)$ (Table 4$)$. HPTLC is an identity test proposed in most of standardization documents for herbal drugs. As using HPTLC is simple, cost effective and rapid detection of herbal drugs 


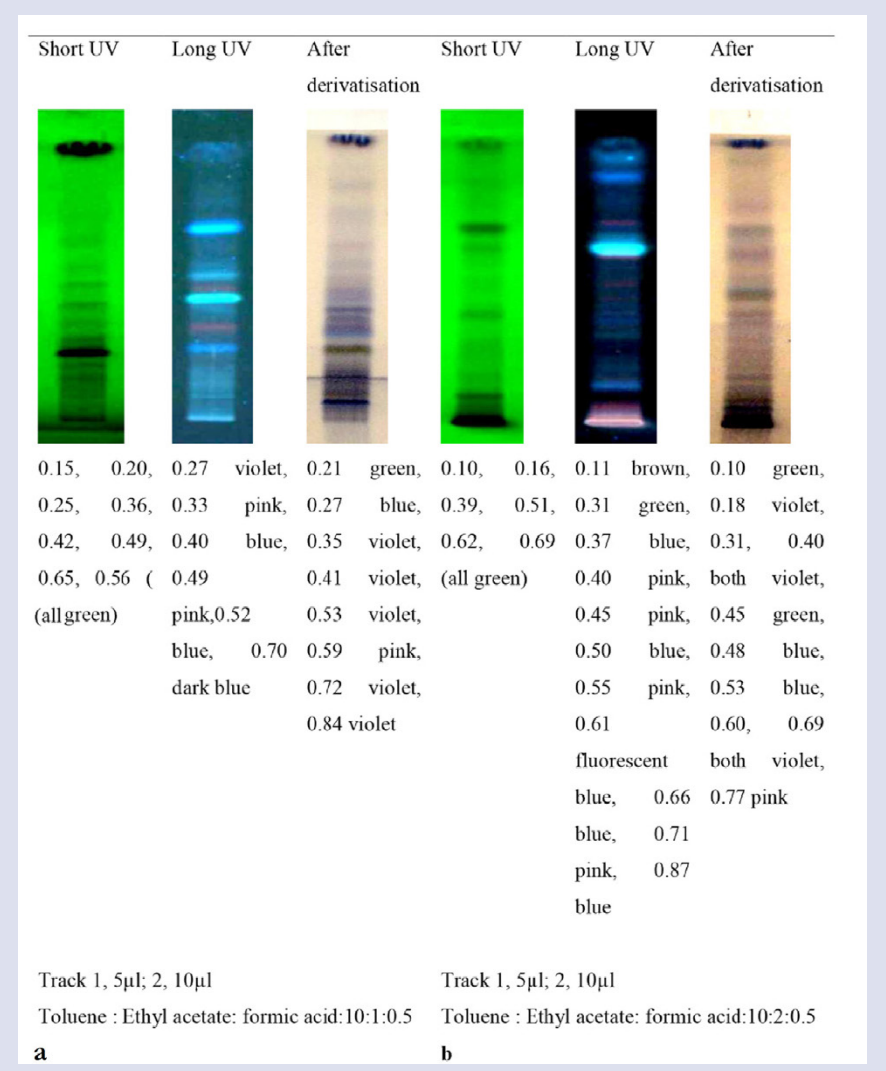

\begin{tabular}{lllllll}
\hline Short UV & Long UV & Affer & Short UV & Long UV & Afler \\
derivatisation
\end{tabular}

Figure 6: TLC photo-documentation of different extracts of Nagakeshara/Sirunagappu. a. n-hexane extract; b. Chloroform extract; c. Ethyl acetate extract; d. Ethanol extract.

Table 1: Fluorescence behavior of Nägakeśara.

\begin{tabular}{cccc}
\hline Powder & Visible light & 254 nm & $366 \mathrm{~nm}$ \\
\hline As such & Brown & Black & No fluorescence \\
With methanol & Brownish yellow & Dark brown & Yellow fluorescence \\
With acetone & Golden brown & Dark brown & Purple fluorescence \\
With ethanol & Brown & Dark brown & Yellow fluorescence \\
With dil. Ammonia & Reddish brown & Brown & No fluorescence \\
With1N methanolic $\mathrm{NaOH}$ & Yellow & Brown & Green fluorescence \\
With $1 \mathrm{~N}$ ethanolic $\mathrm{NaOH}$ & Pale yellow & Brown & Green fluorescence \\
With $1 \mathrm{~N} \mathrm{HCl}$ & Brown & Black & No fluorescence \\
With $50 \% \mathrm{H}_{2} \mathrm{SO}_{4}$ & Brown & Black & No fluorescence \\
With $50 \% \mathrm{HNO}_{3}$ & Brown & Reddish-brown & Nluorescence \\
With $50 \% \mathrm{KOH}$ & Brown & No fluorescence &
\end{tabular}

Table 2: Physico-chemical parameters of Nāgakeśara.

\begin{tabular}{cc}
\hline Parameter & $\%$ w/w (Mean \pm SEM) \\
\hline Loss on drying & $8.505 \pm 0.16$ \\
Water soluble extractive & $5.755 \pm 0.49$ \\
Alcohol soluble extractive & $3.415 \pm 0.47$ \\
Total ash & $3.82 \pm 0.10$ \\
Water soluble ash & $0.38 \pm 0.24$ \\
Acid insoluble ash & $1.03 \pm 0.20$ \\
\hline
\end{tabular}

this chromatographic technique is more in use as identity test unlike other chromatography. Standardization of fingerprint for the drug has been performed in this study for quick identity and quality control.

An earlier report on similar source of crude reported recently claimed the botanical source the drug to be Cinnamomum wightii Meissn. flowers. ${ }^{16}$ However current study clearly shows that the sample are fruits of some Cinnamomum species. In south India there are no scrupulous collections from one particular species of Cinnamomum for this purpose. Many similar looking species of Cinnamomum such as C. zeylanicum, C. malabatrum, C. sulphuratum, C. wightii are collected from wild and traded as 
Table 3: Preliminary phytochemical test for different solvent extracts of Nägakeśara.

\begin{tabular}{ccccc}
\hline Constituents & $n$-Hexane & Chloroform & Ethyl acetate & Ethanol \\
\hline Steroid & - & - & - & - \\
Triterpenoid & + & + & + & + \\
Flavonoid & - & - & + & + \\
Furan & - & + & + & + \\
Sugar & - & - & - & + \\
Coumarin & - & - & - & - \\
Quinone & - & - & + & + \\
Alkaloid & - & - & - & - \\
Tannin & - & - & + & + \\
Phenol & - & - & + & + \\
Acid & - & - & - & - \\
Saponin & - & - & - & - \\
\hline
\end{tabular}

Present (+), Absent (-)

Table 4: HPTLC of ethyl acetate extracts of Nãgakeśara.

\begin{tabular}{ccc}
\hline Peak & $\mathrm{R}_{\mathrm{f}}$ Value & Area \% \\
\hline 1 & 0.05 & 8.44 \\
2 & 0.08 & 0.93 \\
3 & 0.16 & 3.05 \\
4 & 0.20 & 0.74 \\
5 & 0.25 & 7.17 \\
6 & 0.27 & 3.63 \\
7 & 0.31 & 4.56 \\
8 & 0.39 & 0.72 \\
9 & 0.44 & 1.18 \\
10 & 0.46 & 0.67 \\
11 & 0.50 & 1.01 \\
12 & 0.57 & 1.02 \\
13 & 0.62 & 3.36 \\
14 & 0.66 & 0.85 \\
15 & 0.73 & 4.25 \\
16 & 0.77 & 6.78 \\
17 & 0.81 & 2.85 \\
18 & 0.86 & 8.79 \\
\hline
\end{tabular}

Sirunagappu or Nagakesara. Owing to similarity in organoleptic features, same type of confusion already exists about botanical species of Cinnamon bark drugs and leaf drugs too. The pharmacognostical studies are the first and foremost study required on every herbal drug before any further studies are taken. This primary analysis, though are not so sophisticated, are important in herbal drug research while considering adulteration and substitution.

The term Nagakesara in Sanskrit is connected to stamen; hence the source of it must be stamen of flowers. From this fact it can be considered that stamens of Mesua ferrea or some other flower similar to M. ferrea must be the drug. The term Sirunagappu in Tamil connects with a flower, hence a flower must be the source of the drug. One of the flower sources of Sirunagappu/Nagakesara is Ochrocarpus longifolius, hence the same may be considered as Sirunagappu. The drug studied in the current study belongs genus Cinnamomum, but the drug is sold in market as immature fruits not flowers. If Cinnamomum species is to be used as Sirunagappu then the drug must originate from a flower not fruit. Or the drug name could be a misnomer like fruit of Cuminum cyminum is called as cumin seed.

\section{CONCLUSION}

Macro-microscopical and physico-chemical fingerprint standards for the fruit of Cinnamomum species traded in the name of Nagakesara or Sirunagappu is a mixture of immature fruits of many commonly occurring Cinnamomum species of Western Ghats. There are several species of Cinnamomum yielding similar aromatic fruits hence there is need to study flowers and fruits of all the Cinnamomum species occurring in Western Ghats before concluding the botanical source of Sirunagappu to be $C$. wightii. The study also concludes that the botanical Nagakesara or Sirunagappu is neither stamen (as suffixed by Kesara meaning stamen nor flower (as suffixed by Poov meaning flower), but it is immature fruits of Cinnamomum species.

\section{ACKNOWLEDGEMENT}

The author sincerely thanks the Director General, Central Council for Research in Ayurvedic Sciences (CCRAS) and Central Council for Research in Siddha (CCRS) for providing facilities.

\section{CONFLICT OF INTEREST}

The authors declare no conflict of interest.

\section{ABBREVIATIONS}

CC: content cell, Ct: cortex, Cu: cuticle, E: epidermis, Enc: endocarp, Ens: endosperm, GCC: Granular Content Cell, Hyc: hypocarp, IE: inner epidermis, MC: mucilage cells, OE: Outer Epidermis, Pa: parenchyma, Per: pericycle, Ph: phloem, Pi: pith, RT: Remnant Tissue, SC: Stone Cell/sclereid, T: trichome, Te: testa, Ve: vessel, VOC: Volatile Oil Cell, Xy: xylem.

\section{REFERENCES}

1. Roshy JC, llanchezhian R, Patgiri B, Harish CR. Pharmacognostical Study of Nagakeshara (Mesua ferrea Linn.) - An Ingredient in Vyaghrihareetaki Avaleha. IJRAP. 2010;1(2):264-72

2. Anandakumar A, Balasubramanian M, Muralidharan R. Nagakesara - A comparative Pharmacognosy. Ancient Science of Life. 1986;5(4):263-8

3. Rheede HV. Hortus Indicus Malabaricus. Holland: Ametelodami. 1685:1.

4. Hooker JD. Flora of British India. Delhi: B Singh and MP Singh and Periodical experts. 1973;5:128.

5. Gamble JS. The Flora of the Presidency of Madras. Calcutta: Botanical Survey of India; 1967;2:524.

6. Kostermans AJGH. The South Indian Species of Cinnamomum Schaeffer (Lauraceae). Bull Bot Surv India. 1983;25(1-4):90-133.

7. Brindha P, Saraswathy A, Mageswari S, Viajayalakshmi R. Powder microscopy of Amukkurac Curnam. Bull Medico-Ethno-Bot Res. 2004;25(1-4):47-59.

8. Muthiah M, Bonfilius V. Ethnobotanical uses of Cinnamomum species, Tamil Nadu, India. Ethnobot Leaflets. 2008;12(1):150-5.

9. Johansen OA. Plant Microtechnique. New York: Mc Graw Hill. 1940;182-203

10. Quality Control Methods for Medicinal Plant Materials. Geneva: World Health Organization. 1998;25-8.

11. Overton $\mathrm{KH}$. Isolation, purification and preliminary observation in elucidation of structures by physical and chemical methods. Bently KW, Editor. New York:

Cite this article: Arunachalam C, Maheshwari B, Nartunai G, Ilavarasan R, Sunil Kumar KN, Sathiyarajeswaran P. A Pharmacognosy Approach to the Botanical Source of a Cinnamon Fruit Traded as Nagakesara and Sirunagappu in Raw Drug Markets. Pharmacog J. 2019;11(1):81-7. 
Inter science publisher; 1993;34

12. Harborne JB. Phytochemical methods. Jackman H, Editor. London; 1973;70.

13. Sethi PD. High Performance Thin Layer Chromatography. $1^{\text {st }}$ Ed. New Delhi: CBS Publishers and Distributors; 1996:10:1-56.

14. Wagner H, Bladt S. Plant Drug Analysis, A Thin Layer Chromatography Atlas. $2^{\text {nd }}$
Ed. Germany: Springer-Verlag. 1996

15. Saraswathy A, Shakila R, Sunil KKN. HPTLC Fingerprint profile of some Cinnamomum species. Phcog J. 2009;2(8):211-5.

16. Lallo D, Sahu AN, Hemalatha S, Dubey SD. Pharmacognostical and phytochemical evaluation of Cinnamomum wightii Meissn. flowers. Indian Journal of Natural Products and Resources. 2012;3(1):33-9
GRAPHICAL ABSTRACT

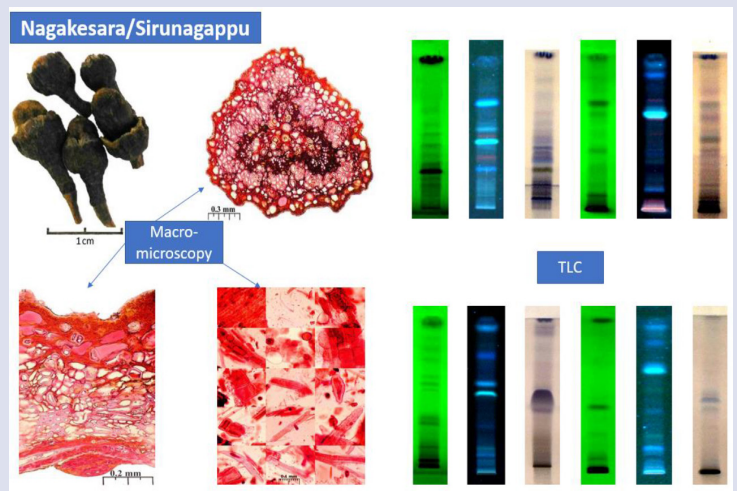

\section{SUMMARY}

- Macro-microscopical and physico-chemical fingerprint standards for the fruit of Cinnamomum species traded in the name of Nagakesara or Sirunagappu is a mixture of immature fruits of many commonly occurring Cinnamomum species of Western Ghats. There are several species of Cinnamomum yielding similar aromatic fruits hence there is need to study flowers and fruits of all the Cinnamomum species occurring in Western Ghats before concluding the botanical source of Sirunagappu to be $C$. wightii. The botanical Nagakesara or Sirunagappu is neither stamen (as suffixed by Kesara meaning stamen nor flower (as suffixed by Poov meaning flower), but it is immature fruits of Cinnamomum species.

\section{ABOUT AUTHORS}

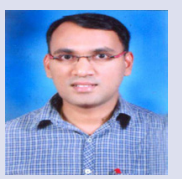

Dr KN Sunil Kumar M.Sc. and Ph.D. (Medicinal Plants -Pharmacognosy specialization served as Senior Research Fellow (ICMR) in 'Quality Standards of Indian Medicinal Plants' project as contributed for 49 monographs. Worked as Senior Research Officer (Pharmacognosy) at SDM Centre for Research in Ayurveda and Allied Sciences, Udupi before joining as Research Officer (Pharmacognosy) at Siddha Central Research Institute, Chennai. Recipient of Seed money to Young scientist for Research Award, Govt. of Karnataka (Citation + Rs. 6 lakhs grant) and Dr. PD Sethi award for 6 best HPTLC papers on traditional medicine. Served as Principal Investigator, RGUHS project (Rs. 5 lakhs grant) and Co-Investigator, UGC project (Rs. 8.87 lakhs grant), CoInvestigator, 4 RGUHS projects (Rs. $8.5+3+5+3$ lakhs grant) and Co-Investigator, PCIM (AYUSH) projects (10 lakhs grant). Author of 118 (6 SCl, 6 ESCl, 5 PubMed, 22 Scopus) research papers/ editorial articles. Attended 13 national / international conferences, 3 as invited speaker. Serving as Chief Editor 'Journal of Ayurvedic and Herbal Medicine', Subject editor - Pharmacognosy 'AYU - An International Quarterly Journal of Research in Ayurveda', Publishing editor - 'Journal of Research in Siddha Medicine', Executive Editor 'Journal of Ayurveda Medical Sciences', Associate Editor 'The Journal of Phytopharmacology', Executive editor 'Research and reviews: Pharmacognosy and Phytochemistry', Editorial advisory board member 'Journal of Scientific and Innovative Research' and 'Journal of Traditional Medicine and Clinical Naturopathy' and Editorial board member 'Journal of Pharmacognosy and Natural Products' and 'Traditional Medicine Reesearch'. Guided 15 MD (Ayu) theses. Attended 9 training programmes in Pharmacognosy, Phytochemistry and quality control aspects. Life member of Society of Pharmacognosy. Biological Scientist - Institutional Animal Ethics Committee, SCRI Chennai. 12 years and 2 months of research experience till September 30th 2018. The field of interest is quality control and standardization of traditional medicine. 